\title{
PENCIPTAAN FILM PENDEK TERINPIRASI DARI KOTAK PERTANYAAN PELAJARAN KHAS DI SD EKSPERIMENTAL MANGUNAN
}

\author{
Philipus Nugroho Hari Wibowo \\ Institut Seni Indonesia Yogyakarta \\ philipus.bowo@isi.ac.id
}

\begin{abstract}
Abstrak: Makalah ini berisi proses kreatif membuat Film Pendek yang ceritanya terinspirasi oleh Kotak Pertanyaan konsep pembelajaran Khas di Sekolah Dasar Mangunan Eksperimental. Kotak Pertanyaan adalah salah satu konsep pendidikan (pembelajaran) yang disampaikan oleh Pastor YB Mangunwijaya. Kotak pertanyaan membiasakan anak-anak untuk menghasilkan pertanyaan setiap hari. Film ini menunjukkan bagaimana perlunya memberi anak-anak kebebasan untuk bertanya untuk mendukung kreativitas anak. Film ini memberikan pandangan lain tentang pendidikan yang baik dan efektif di Indonesia.
\end{abstract}

Kata kunci: film pendek, kotak pertanyaan, Mangunwijaya, Sekolah Eksperimental Mangunan

\begin{abstract}
This paper contains the creative process of creating Short Films whose stories are inspired by the Question Box of a Typical learning concept in the Experimental Mangunan Primary School. The Question Box is one of the concepts of education (learning) presented by Father YB Mangunwijaya SJ. Question boxes familiarize children to produce questions every day. The film shows how the need to give children the freedom to ask questions to support children's creativity. This film provides another view regarding good and effective education in Indonesia.
\end{abstract}

Key words: Short Movie, Question Box, YB Mangunwijaya, Mangunan Experimental Elementary School

\section{Pendahuluan}

Dunia anak merupakan dunia yang penuh dengan keindahan dan kebebasan. Rasa ingin tahu yang berlebih membentuk kerangka berfikir untuk kritis dan kreatif. Sayangnya rasa ingin tahu anak-anak sering kali diangap kurang pas dan masalah bagi sebagian besar orang dewasa. Anak-anak seakan tidak boleh tahu sesuatu hal yang belum sepatutnya mereka tahu. Padahal dengan membatasi rasa ingin tahu anak-anak secara tidak langsung akan menghambat kreativitas dan pola berfikir anak.

Kotak Pertanyaan adalah salah satu Konsep Pendidikan (pembelajaran) yang di Kemukakan ole Romo YB Mangunwijaya SJ. Kotak Pertanyaan membiasakan anak untuk memproduksi pertanyaan setiap hari, pertanyaannya adalah tentang apapun baik hal yang sepele sampai hal yang sangat filosofis, dari hal yang sensitif hingga hal yang sangat biasa. Kotak Pertanyaan menjadikan anak sangat kritis dengan lingkungannya. Rasa ingin tahu mereka bisa direspon dengan bijak. Pada akhir minggu kotak pertanyaan tersebut akan dibuka dan diklasifikasi oleh guru wali kelas masingmasing. Pertanyaan mana yang bisa dijawab dengan langsung, dan pertanyaan mana yang membutuhkan narasumber untuk menjawab atau menjelaskannya dan mana yang perlu dijawab dengan literatur.

Proses bertanya pada anak tentunya sudah dimulai sejak mereka mulai 
berinteraksi dan belajar mengenali lingkungan yang ada disekitar mereka, sehingga mereka akan terus mengalami pekembangan dalam hidupnya. Ini adalah sebuah tahap di mana seseorang punya kesadaran diri untuk memperhatikan, mempelajari, dan menekuni segala hal yang dialaminya sehari-hari secara terus-menerus.

Kotak Pertanyaan ini dikembangkan oleh Romo Mangunwijaya di sekolah Dasar Eksperimental Mangunan di Daerah Kalitirto Berbah Sleman sebagai pelajaran khas beserta beberapa konsep belajar lainnya yaitu Komunikasi Iman, Pendidikan Seni, Baca Buku Bagus dan Majalah Meja. Sekolah ini didirikan Romo Mangun sebagai bentuk keprihatinannya kepada masyarakat supaya menjadi semakin cerdas adil dan manusiawi, Sekolah Mangunan memiliki kurikulum yang sedikit berbeda dengan pendidikan yang dibuat oleh pemerintah, hal ini lah yang kemudian justru menginspirasi berdirinya berbagai sekolahsekolah alternatif di Yogyakarta.

Romo Mangun terkenal sangat humanis. Hal ini tampak dalam tindakannya yang terus memperjuangkan hak-hak rakyat kecil. Bagi Romo Mangun, pengabdi rakyat kecil bukanlah mendoktrinir dan memimpin, melainkan mengaktualisasikan potensi yang sudah ada dalam rakyat, namun belum lepas dari selubung. Potensi yang ada dalam diri masyarakat itu sangat kaya dan bermutu, namun tidak dapat dikembangkan karena tidak mempunyai dasar yang kuat. Hal seperti ini sangat tampak dalam diri rakyat kecil. Alasan inilah yang menggerakkan Romo Mangun untuk memperjuangkan dan mengarahkan rakyat kecil menjadi semakin cerdas dan manusiawi.

Ide tentang Kotak pertanyaan sangat menarik untuk di filmkan, apalagi Karakter anak-anak masa kini yang aktif dan dinamis perlu ditanggapi secara positif. Sekolah Dasar Eksperimental Mangunan yang sangat berbeda dari sekolah yang lain juga menjadi tawaran artistik yang menarik dalam film nantinya. Secara penampilan Sekolah Mangunan sangat artistik dengan kelas yang berdinding kayu (gebyok), berlantai konblok, letak Sekolah Dasar Eksperimental Mangunan yang dekat sekali dengan rel kereta api, membuat Mangunan menjadi menarik secara auditif. Romo Mangun sendiri yang merupakan konseptor Kotak Pertanyaan juga tidak diragukan kredibilitasnya baik sebagai tenaga pendidik, budayawan, sastrawan dan juga rohanian. Jadi pemilihan ide kotak pertanyaan jelas tepat.

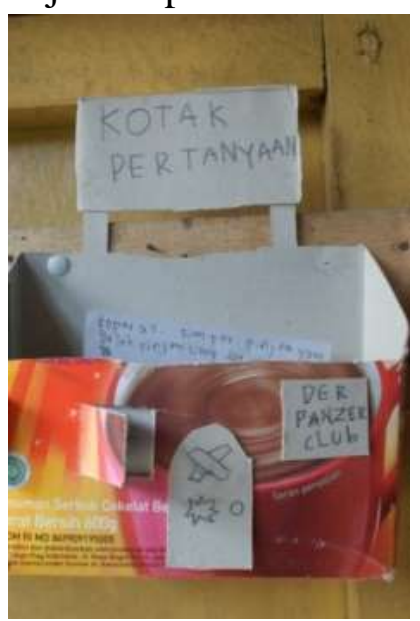

Gambar 1. foto Kotak Pertanyaan

(Foto: www.mylittlelolipop.wordpress.com 2009)

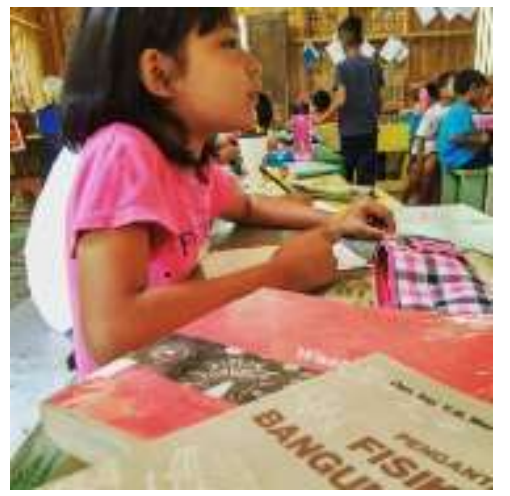

Gambar 2. Aktivitas SD E Mangunan (Foto : Yohanes Carol- 2016)

Film ini akan memperlihatkan bagaimana caranya seorang anak bisa memunculkan pertanyaan yang kreatif, tidak 
terduga, bahkan tabu. Lantas bagaimana cara guru menjawab dan menjelaskan berbagai pertanyaan tersebut, mengingat ada hal-hal yang sangat sensitife dan terkesan kurang pas. Film ini tidak hanya menarik untuk dikonsumsi anak-anak akan tetapi juga sangat menarik untuk orang dewasa khususnya orang tua. Pada film ini akan diperlihatkan, bagaimana caranya memberikan ruang kepada anak-anak untuk mengembangkan rasa keingin tahuannya. Apabila dibuat sebuah logline, maka dalam film ini adalah:

“...Bagaimana jika seorang anak
berumur 9 tahun menanyakan
kegelisahannya (tentang pertengkaran
orang tuanya) dalam sebuah kotak kecil,
padahal hal ini belum mampu ia pahami,
dan kemudian ia tetap bersikukuh ingin
mengert hal tersebut".

Sejauh ini film-film anak yang mengambil sudut pandang pendidikan selalu mengkritisi pendidikan Indonesia yang sangat memprihatinkan, dari film Laskar Pelangi, Denias, Tanah Surga Katanya dan masih banyak yang lain. Film- Film tersebut memang menghadirkan realitas Pendidikan di Indonesia. Meskipun kita menyadari bahwa Pendidikan Indonesia masih banyak memiliki celah-celah kekurangan, ternyata masih ada pendidikan di Indonesia yang bagus, salah satunya adalah SD Eksperimental Mangunan. Berkaitan dengan hal tersebut akan sangat menarik jika perlu dihadirkan pula sisi lain Pendidikan di Indonesia (Pendidikan yang baik). Melalui Film yang akan pencipta buat nantinya akan diperlihatkan bahwa masih ada pendidikan di Indonesia yang memiliki nilai plus untuk perkembangan bangsa dan Negara tentunya.

\section{Teori}

Film dikenal dengan konsep filmis yaitu penceritaan melalui gambar (Sumarno, 1997). Analisis film berarti memisahkan atau memecah-mecah suatu kebulatan menjadi bagian-bagian dan kemudian meneliti sifat-sifat, proporsi, fungsi, serta saling berhubungan dari bagian- bagian ini. (Marceli, 1986).

Secara umum film dapat dibagi menjadi dua unsur pembentuk yakni, unsur naratif dan unsur sinematik. Keduanya saling berinteraksi dan berkesinambungan satu dengaan yang lain untuk membentuk sebuah film. Prastista (2008) dalam bukunya yang berjudul Memahami Film menyatakan bahwa unsur naratif berhubungan dengan aspek cerita atau tema film. Maka aspek naratif film pada dasarnya memiliki struktur yang sama dengan struktur cerita rekaan yaitu penokohan, dialog, alur cerita, latar dan tema. Unsur sinematik adalah aspekaspek teknis dalam sebuah film seperti mise en scene, sinematografi, editing dan suara. Maka dapat disimpulkan bahwa unsur naratif adalah bahan (materi) yang akan diolah dalam film, sementara unsur sinematik adalah cara (gaya) untuk mengolahnya.

\section{Teori Adaptasi}

Adaptasi adalah suatu usaha untuk membuat sebuah hasil karya baru dari sumber lain atau dari satu media ke media yang lain dengan mempertahankan atau melakukan variasi pada lakuan, tokoh serta gaya dan nada aslinya (Wibowo, 2015). Krevolin (2003) mengatakan, dalam melakukan adaptasi kita memiliki kebebasan dan memiliki beban untuk membuat cerita menjadi lebih menarik. Cerita yang anda tulis harus lebih gamblang, mengalir dengan cepat, dan lebih lucu dari pada bahan sumber. Cerita anda harus lebih sarat adegan, lebih mendebarkan hati, dan lebih seksi dari pada cerita aslinya. Tujuan adaptasi bukanlah untuk mempertahankan sebanyak mungkin kemiripan dengan cerita aslinya, melainkan untuk membuat pilihan terbaik dari materi yang ada untuk menghasilkan skenario sebaik mungkin. Inti 
dari adaptasi adalah perubahan bentuk, tidak hanya terbatas pada seting, penokohan, alur tapi bisa apapun (Wibowo, 2015).

Proses adaptasi harus memiliki nilai yang lebih dari sumber-sumbernya. Upaya Adaptasi dari satu bentuk naskah kebentuk lain (teks) sudah terjadi dan terus berlangsung (Philipus, 2012). Dalam proses adaptasi pasti akan berkaitan dengan Intertekstualitas, karena dalam melakukan pembacaan Teks memerlukan pemahaman terhadap teks-teks yang sudah ada sebelumnya. Oleh karena itulah teks baru memerlukan pemahaman teks-teks yang telah mendahuluinya. Seperti halnya yang disampaikan oleh Kristeva bahwa setiap teks merupakan mozaik kutipan yang berasal dari semestaaan yang anonim, penulis hanya menyusunnya. (Ratna. 2001). Maka dalam proses adaptasi perlu dilacak lagi teks-teks yang sudah mendahului yang berkaitan dengan topik penciptan.

\section{Metode}

Dalam mewujudkan karya film,
terlebih dahulu penulis merujuk pada
tahapan-tahapan penciptaan kreatif yang
dikemukakan oleh Graham Wallas dalam
buku Psikologi Seni karangan Irma
Damayanti (2006). Tahapan-tahapan
tersebut yaitu, (a) Preparation (Persiapan),
(b) Incubation (pengeraman), (c)
Ilumination (tahap ilham, inspirasi), (d)
Verification (tahap pembuktian atau
pengujian).

\section{Tahap Preparation (Persiapan)}

Tahap ini merupakan pengumpulan informasi atau data yang diperlukan untuk memecahkan suatu masalah. Dengan bekal bahan pengetahuan maupun pengalaman, individu menjajagi bermacam-macam kemungkinan penyelesaian masalah. Disini belum ada arah yang pasti/tetap, akan tetapi alam pikirannya mengeksplorasi macammacam alternatif (Damayanti, 2006).
Pada tahap ini penulis melakukan riset tentang Kotak Pertanyaan dan Romo Mangunwijaya, melalui berbagai teks, wawancara dengan nara sumber dan hadir di sekolah Mangunan untuk melihat realisasi Kotak Pertanyaan. Hal ini dilakukan supaya penulis mendapatkan gambaran secara jelas tentang Kotak Pertanyaan.

\section{Tahapan Incubation (inkubasi)}

Tahapan ini adalah tahap ketika indvidu seakan-akan melepaskan diri untuk sementara dari masalah tersebut, dalam arti ia tidak memikirkan masalah secara sadar, tetapi mengeraminya dalam alam pra sadar, tahap ini penting artinya dalam proses timbulnya inspirasi (Damayanti, 2006).

Setelah data dan informasi terkumpul, maka akan muncul banyak gagasan. Pada tahap ini bahan mentah kemudian diolah dan diendapkan.Penulis merangkum semua data dan mengakumulasi menjadi satu bagian. Penulis mulai memilah data-data mana yang relevan untuk dipakai dan menjadi gagasan atau inspirasi.

\section{Tahap Ilumination (Iluminasi)}

Tahapan ini adalah tahap timbulnya insight Atau Aha-Erlebins, saat timbulnya inspirasi atau gagasan baru, beserta prosesproses psikologis yang mengawali dan mengikuti munculnya inspirasi/gagasan baru (Damayanti, 2006).

Jika tahap sebelumnya masih bersifat dan bertaraf mencari-cari dan mengendapkan, pada tahap ini semua menjadi jelas dan terang. Pada saat inilah seorang penulis akan merasakan katarsis, kelegaan dan kebahgaiaan karena apa yang semua menjadi gagasan dan samar- samar akhirnya menjadi sesuatu yang nyata. Pada tahap ini penulis kemudian memanifestasikan data-data yang telah didendapkan sebelumnya.

Pada tahap ini penulis melakukan manifestasi ide-ide dan data yang sudah ada 
dengan melakukanproses penciptaan film dari pra produksi, produksi hingga pasca produksi.

Pada tahapan pra produksi, sutradara bekerja sama dengan produser melakukan, pembentukan crew baik artistik dan crew produksi, scheduling dan pembuatan anggaran produksi. Setelah itu bersama tim artistik sutradara melakukan pemilihan pemain (casting), hunting lokasi, bedah skenario, reading, bloking, dan rehearshal yang disiapkan untuk tahap berikutnya (produksi- shoting). Tahap pra produsi sangat penting dilakukan. Apabila proses pra produksi dirasa belum selesai/cukup (matang), lebih baik dipersipakan hingga matang. Oleh karena, ketidak siapan dalam pra produksi akan berakibat fatal (menghambat) bagi proses produksi (Shoting).

Setelah pra produksi betul-betul matang. Proses produksi bisa berjalan. Pada saat produski belangsung, sutradara bertugas memimpin semua crew dan memberikan solusi yang tepat juga bijak, apabila ada kendala/kecelakaan yang diluar dugaan.Mood sutradara sangat berperan dalam menunjang proses lancarnya shooting. Sutradara memberikan pengarahan kepada para pemain melalui asisten sutradara baik dalam penokohan, bloking ataupun penjadwalan dan tetap berkoordinasi dengan tim produksi yang dipimpin oleh seorang produser.

Setelah produksi berakhir, bahan/materi yangberupa stok-stok shot adegan akan dirangkai pada proses editing, kemudian diberi ilustrasi musik. Sutradara mengarahkan editor berkaitan dengan hasil shoting yang akan dirangkai. Hingga hasil akhir berupa film siap tayang.

Tahap Verification (Pembuktian atau pengujian)

Tahapan ini disebut juga tahapan evaluasi, ialah ketika ideatau kreasi baru tersebut harus diuji terhadap realitas. Disini diperukan pikiran kritis dan konvergen. Dengan perkaaan lain, proses divergensi (pemikiran kreatif) harus diikuti oleh proses konvergensi (pemikiran kritis) (Damayanti 2006). Tahap ini disebut juga tinjauan secara kritis, dalam tahap ini penulis melakukan evaluasi terhadap karya ciptanya jika diperlukan ia bisa melakukan modifikasi, revisi dan lain-lain. Pada tahap ini penulis melakukan evaluasi dan revisi terhadap film.Film kemudian diberikan kepada beberapa orang yang sengaja dipilih untuk memberikan komentar (apresiasi) dan masukan yang membangun tentang film. Apabila dirasa pas, masukan tersebut dapat digunakan untuk semakin memperkuat film, sehingga hasil sesuai dengan apa yang diharapkan

\section{Hasil dan Pembahasan}

Setelah melalui tahap demi tahap proses penciptaan dengan menerapkan Metode Penciptaan dan Landasan Teori yang dipilih, maka didapatkan hasil Penciptaan/penelitian berupa Film pendek yang berdurasi sekitar 24 menit berjudul "koper Gendis" Mencari Jawab Menakar Tanya. Meskipun film ini menggunakan lokasi Sekolah Dasar Eksperimental Mangunan dan anak-anak sebagai Point Of View, Film ini dikhususkan untuk orang dewasa dan butuh pendampingan jika dikonsumsi anak-anak. Tahapan-tahapan penciptaan dibagi menjadi Praproduksi, Produksi dan Pasca Produksi.

\section{Pra Produksi}

Pada tahapan pra produksi, terdapat sebuah tahapan yang dikenal dengan istilah triangle system yang meliputi Produser, Penulis Skenario dan Sutradara. Ketiganya berkolaborasi untuk mewujudkan film yang sudah disepakati sebelumnya dalam sebuah konsep sesuai dengan tugasnya masingmasing. Proses kerja pembuatan skenario 
merupakan langkah paling awal dalam pembuatan film. Skenario berfungsi sebagai acuan dalam pembuatan film. Skenario digunakan untuk mem-breakdown semua kebutuhan pembuatan Film. Skenario memuat arahan dan petunjuk untuk membuat film. Skenario menjadi hal yang penting dalam pembuatan film, karena Skenario meruapakan Blue Print atau rancangan dalam membuat film.

$$
\text { Setelah Penulis Skenario }
$$

menyelesaikan Skenario, sutradara bekerja sama dengan produser melakukan, pembentukan crew baik artistik dan crew produksi, scheduling dan pembuatan anggaran produksi. Setelah itu Sutradara bersama tim artistik melakukan pemilihan pemain (casting), hunting lokasi, bedah skenario, reading, bloking, dan rehearsal yang disiapkan untuk tahap berikutnya (produksi- shoting). Tahap pra produksi sangat penting dilakukan. Apabila proses pra produksi dirasa belum cukup (matang), lebih baik produksi diundur hingga persiapan benar-benar matang dan sempurna. Kecerobohan dalam hal ersiaan pra produksi aka berakibat fatal (menghambat) bagi proses produksi (Shoting).

\section{Casting}

Casting dilakukan setelah terlebih dahulu mencermati karakter tokoh yang dibutuhkan dalam Skenario, pemilihan pemain merupakan bagian yang penting, mengingat bukan hanya kemampuan secara akting yang menjadi pertimbangan, akan tetapi mencangkup hal yang lain seperti aktvitas dan atitude seseorang. Jadwal pemain yang terlalu padat, dan atitude yang tidak baik akan menghambat proses Produksi film. Pada film ini terdapat 6 tokoh yang terdiri dari Gendis (Utama), Yanti, Bambang, Dayu, Bayu dan John.

Tokoh Gendis diperankan oleh Abel seorang siswa kelas 4 SD Eksperimental Mangunan. Gendis adalah anak kelas 4 SD, umurnya sekitar 8 tahun. Ia anak yang smart dan kritis dalam menyikapi apapun. Meskipun ia hidup di keluarga Bangsawan, namun ia dididik untuk mandiri. Tak sengaja ia sering melihat percecokan kedua oang tuanya. Ia kaget, ketika tahu Ayahnya sering melakukan kekerasan pada Ibunya. Hal ini tentunya belum pas untuk anak seusianya. Beruntung ada Kotak pertanyaan di sekolahnya. Ia jadi bisa menanyakan kegelisahan melalui kotak pertanyaan, sayangnya sampai minggu ke empat, pertanyaan yang ia buat tak juga ditanyakan, ia gelisah, rasa ingin tahunya tinggi. Jangankan ingin tahu jawaban, kertas pertanyannya ternyata tak ada di koper. Gendis tak pantang menyerah, ia terus berusaha untuk mencari kertas dan mendaptakan jawaban tentang kegelisahannya.

Tokoh Yanti Diperankan oleh Ninda, seorang mahasiswi tingkat Akhir salah satu Kampus Swasta di Yogyakarta. Yanti adalah seorang perempuan desa, parasnya yang ayu membuat Bambang membelinya dari kedua orang tuanya yang tinggal di pesisir pantai Gunung Kidul. Saat itu umurnya masih 15 tahun. Ia seorang wanita penurut, apapun yang diperintahkan oleh suaminya pasti ia turuti. Awalnya Yanti sangat lugu layaknya gadis desa. Perlahan-lahan Bambang membimbingnya dalam berbagai hal, pendidikan, Tata Krama dan bagaimana menjadi perempuan Jawa (bangsawan).

Meskipun Bambang sering begitu kasar padanya, ia tidak berani melawannya. Bambang yang masih keturunan darah biru itu seperti halnya nabi baginya yang selalu bersikap benar. Akan tetapi lambat laun, Yanti merasa harus bisa lepas dari ketidak berdayaan dirinya dari suaminya. Keberaniannya mulai muncul ketika Bambang marah besar padanya, ketika tahu Yanti menjual Kain Lurik dan produk lainnya kepada pedagang-pedagang kaki lima di parkiran bus Pariwisata. Hal itu Aib 
bagi Bambang yang merasa keluarga Bangsawan Terhormat. Bambang marah besar, Yanti memberanikan diri menjawab untuk klarifikasi, hatinya sudah semakin meradang. Tapi baru satu kata terucap dari mulutnya, Bambang makin emosi dan melampiaskan kemarahannya. Lagi-lagi Yanti terdiam, tertunduk dan tak berdaya. Di sela ketidakberdayaannya ia menyimpan suatu kekuatan untuk berani melawan.

Bambang diperankan oleh Wahid Nurcahyono (Dosen Program Studi Teater ISI Yogyakarta). Bambang adalah Ayah Gendis, ia seorang Ningrat, keturunan bangsawan Jawa. Kini ia yang dipercaya meneruskan usaha keluarganya, sebuah Pabrik kain lurik. Bambang harus memutar otak supaya Pabrik Luriknya tidak tutup tergerus zaman seperti pabrik lainnya. Kini hanya tinggal dua buah pabrik Lurik yang masih berproduksi.

Bambang bertemu dengan Yanti ketika ia berkunjung ke pesisir pantai Gunung Kidul. Paras Yanti yang ayu dan kehidupannya yang miskin membuatnya iba untuk mengangkatnya dari jurang kemiskinan. Menikah dengan Yanti adalah cara Bambang menyembunyikan status dirinya yang sebetulnya menyukai sesama jenis. Sikap Bambang yang teduh pada Yanti berubah ketika ia tahu anak yang dilahirkan Yanti perempuan. Ia sangat berharap laki-laki, yang akan meneruskan dirinya kelak. Kini Bambang sering marah pada Yanti ketika ada sesuatu yang tidak sesuai dengan harapan Bambang, bahkan kekerasan sering ia lakukan pada Yanti. Yanti menerima dan pasrah. Ia tak bisa berbuat apa-apa. Bambang begitu menyanyangi dan mencintai Gendis. Ia mencoba menjadi seorang bapak yang baik di depan Gandis.

Kejengkelan Bambang pada Yanti memuncak ketika ia tahu Yanti berjualan kain lurik di pemberhentian bis pada pedagang kaki lima. Ini hal yang sangat buruk bagi Bambang. Ini sama saja mencoreng wajah keluarga besarnya. Apalagi Yanti tiba-tiba berani untuk menyela kata-katanya. Pikirannya makin kacau ketika tahu Gendis lesu dan hanya mengurung diri di kamarnya, ia tak tahu apa yang sedang terjadi pada Gendis, sementara beberapa hari lagi ia harus berangkat ke Belgia untuk menghadiri pameran krajinan dan bertemu dengan Mr. Bayu kekasihnya. Ia sengaja menyuruh Mr. Bayu, untuk mendekati Mr. John supaya ia diberi akses memamerkan Lurik buatannya ke luar Negri. Bu Dayu diperankan oleh Retno, seorang guru SD Mangunan, sedangkan $\mathrm{Mr}$ Bayu diperankan oleh Deka dan Mr. Jhon diperakan oleh Sergei.

\section{Hunting}

Hunting dilakukan untuk memilih
lokasi yang akan dipakai dalam pengambilan gambar, setelah sutradara merasa cocok, tim artistik dan tim Produksi bertugas untuk mendata kebutuhankebutuhan yang diperlukan. Kebutuhan seting film adalah Sekolah Mangunan, rumah Bangsawan Jawa, Pabrik Lurik dan jalanan seputar Yogyakarta.

Latihan

Untuk mendapatkan hasil yang maksimal, latihan sangat perlu dilakukan, baik latihan untuk para pemain (reading, dan bloking) ataupun latihan dari tim teknis seperti halnya pergerakan kamera. Butuh penyesuaian yang sifatnya sangat teknis, karena pergerakan kamera dan peletakan kamera dalam pembuatan Film sangat terukur.

Produksi

Setelah proses pra produksi betul-betul matang. Proses produksi bisa berjalan. Pada saat produski berlangsung, sutradara bertugas memimpin semua crew dan memberikan solusi yang tepat juga bijak, 
apabila ada kendala/kecelakaan yang diluar dugaan. Mood sutradara sangat berperan dalam menunjang proses lancarnya shooting. Sutradara memberikan pengarahan kepada para pemain melalui asisten sutradara baik dalam penokohan, blocking ataupun penjadwalan dan tetap berkoordinasi dengan tim produksi yang dipimpin oleh seorang produser.

\section{Pasca Produksi}

Setelah produksi berakhir, bahan/materi yang berupa stok-stok shot adegan akan dirangkai pada proses editing, kemudian diberi ilustrasi musik. Sutradara mengarahkan editor berkaitan dengan hasil shoting yang akan dirangkai. Hingga hasil akhir berupa film siap tayang.

\section{Simpulan}

Penciptaan Karya seni yang berjudul Mencari Jawab Menakar Tanya, Penciptaan Film Pendek Terinspirasi dari Kotak Petanyaan Pelajaran Khas di SD Ekperimental Mangunan telah melalui tahapan-tahapan yang sistematis. Hasil karya akhir berupa Film pendek berdurasi 24 menit 15 Detik yang berjudul "Koper Gendis, Mencari Jawab Menakar Tanya" beserta skenario film final draft. Penciptaan film ini memperlihatkan bagaimana perlunya memberi kebebasan bertanya kepada anak-anak untuk menunjang kreatifitas anak-anak.

Film ini memberikan pandangan lain berkaitan pendidikan yang baik dan efektif di Indonesia, selain itu Penciptaan ini diharapkan memberikan wacana baru, sumbangan ilmu dalam perkembangan film Indonesia tentang sudut pandang lain dari film pendidikan di Indonesia. Film ini harapannya memberikan penyeimbang tentang pandangan Pendidikan di Indonesia. Film ini diharapkan memberikan kecemburuan positif kepada pembuat film baik yang profesional maupuan tidak untuk kemudian menciptakan karya film yang baru, sehingga ikut meramaikan perkembangan dunia perfilman Indonesia.

Pembuatan film dengan melibatkan anak-anak sebagai pemain, membutuhkan penanganan khusus mengingat mood anakanak sering berubah tak menentu, hal yang tak akalah pentingnya adalah status mereka yang masih pelajar yang setiap hari bersekolah, hal ini membuat tim membutuhkan strategi khusus dalam hal penjadwalan shoting. Perlu adanya konsep distribusi dalam penciptaan karya, khususnya film. Sehingga setelah karya film ini selesai akan terus bisa diapresiasi di ruang-ruang apresiasi yang lain, baik pemutaran Film secara personal maupun Festival Film baik nasional maupun internasional. Pada akhirnya hasil Film ini Diwujudkan sebagai salah satu upaya untuk mencari alternative dalam mencari ide dalam penciptaan film.

\section{Daftar Pustaka}

Damayanti, I. (2006). Psikologi Seni, Bandung: Kiblat Buku Utama.

Krevolin, R. (2003). Rahasia Sukses Skenario Film- Film Box Offiice, 5 Langkah Jitu Mengadaptasi Apapun Menjadi Skenario Jempolan. Bandung: Mizan Media Utama.

Prastista, H. (2008). Memahami Film. Yogyakarta: Homerian Pustaka.

Ratna, K. (2001). Teori, Metode, dan Teknik Penelitian Sastra. Yogyakarta: Pustaka pelajar.

Sumarno, M. (1997). DA Peransi dan Film. Jakarta: Lembaga Studi Film.

Wibowo, P.N.H. (2015). Novel Gadis Pantai Karya Pramoedya Ananta Toer Sebagai Dasar Penciptaan Skenario, Jurnal Rekam 11 (1). 